\title{
Contemporary condition and development prospects of international logistics in the post-sanction period
}

\author{
Negreeva Valentina Vladimirovna \\ Chair of Economics and Law \\ Saint-Petersburg University of State \\ Fire Service of Emercom of Russia \\ Saint-Petersburg, Russia \\ v.negreeva@mail.ru \\ ORCID 0000-0003-3017-0839
}

\author{
Soultygova Milana Beslanovna \\ Chair of Economics and Law \\ Saint-Petersburg University of State \\ Fire Service of Emercom of Russia \\ Saint-Petersburg, Russia \\ soultygova@mail.ru \\ ORCID 0000-0002-0380-9206
}

\author{
Medvedeva Olga Evgenievna \\ Faculty of Technology Management \\ and Innovation \\ Saint - Petersburg National Research \\ University of Information Technologies, \\ Mechanics and Optics \\ Saint-Petersburg, Russia \\ olmed@inbox.ru \\ ORCID 0000-0002-2381-1928
}

\author{
Filimonova Alexandra Viktorovna \\ Faculty of Technology Management \\ and Innovation \\ Saint - Petersburg National Research \\ University of Information Technologies, \\ Mechanics and Optics \\ Saint-Petersburg, Russia \\ sfi197@mail.ru \\ ORCID 0000-0001-9698-6502
}

\begin{abstract}
International logistics in Russia underwent enormous changes in 2014, after the introduction of economic sanctions. In connection with the current situation on the international market, Russian logistics has faced a large number of problems that need to be addressed for its further development. One of them is the reorientation of logistics flows.
\end{abstract}

Key words - digitalization, logistics, international logistics, foreign economic activity, sanctions.

\section{INTRODUCTION}

In the context of the globalization of the economy, the aggravation of the geopolitical situation and the prevailing conditions that are associated with the sanctions imposed against Russia, foreign economic activity and, in aggregate, international logistics are becoming of great importance not only for the state as a whole, but also for individual enterprises. The listed reasons form the tendency of closure of the national economic system [1], but also allow the formation of new forms of development of the logistics sphere. Therefore, the authors of the article set a goal to investigate the contemporary condition of international logistics and the prospects for its development in the postsanction period; identify factors to identify the main trends in the development of international logistics; to analyze the changes associated with export-import operations in the Russian Federation, which will expand opportunities in the competition.

\section{MATERIALS AND METHODS}

Global logistics and integration have a significant impact on contemporary logistics. Despite all the financial and economic difficulties, the volume of international trade is growing annually, so the total volume of world exports in 2017 amounted to about \$20,000 billion. According to experts of the World Trade Organization, this increase is due primarily to higher prices for basic goods, physical volumes trade rose slightly. Today, the largest exporting countries include China, the USA, Canada, Germany, Japan and the Netherlands. Import leaders are the USA, China, Japan and France [2].

In March 2014, the first sanctions were imposed on Russia in connection with the official policy regarding events taking place in Ukraine. These measures were originally imposed by the United States of America, then they were supported by other states - countries of the European Union, Great Britain, Canada, Australia, Japan. The bans applied to investments from Europe in the transport, telecommunications, industrial sectors of the economy in the Crimea. On August 6, 2014, the President of Russia signed Decree No. 560 "On the Application of Certain Special Economic Measures to Ensure the Security of the Russian Federation" and political and economic measures were taken in response. This document provided for restrictions on Russian authorities, organizations, legal entities and individuals on the implementation of foreign economic activity (FEA). The ban applied to the import of certain types of agricultural products, raw materials and foodstuffs from states that support the sanctions regime against the Russian Federation [3].

Consider some features of the development of world logistics in relation to the Russian Federation. In the period from 2014 to 2015, indicators of the effectiveness of foreign economic activity declined sharply, as shown in the graph reflecting results 1 [4].

In connection with the growth of trade, the volume of cargo transportation in international traffic annually increases. Also, one of the most important trends in contemporary international logistics is the growth in container traffic. [5] This method of cargo delivery is the most progressive, it allows to achieve the greatest safety of 
cargo, significantly reduces the cost of transportation and storage, increases the speed of delivery. An analysis of the container transportation market showed that the volume of container transportation from 1990 to 2014 increased by almost 7 times, while the growth rate of dry bulk cargo and oil transportation increased by 3 and 2.5 times, respectively. Currently, about $60 \%$ of cargo is transported in containers. In Russia, container shipping is experiencing difficulties due to a number of reasons:

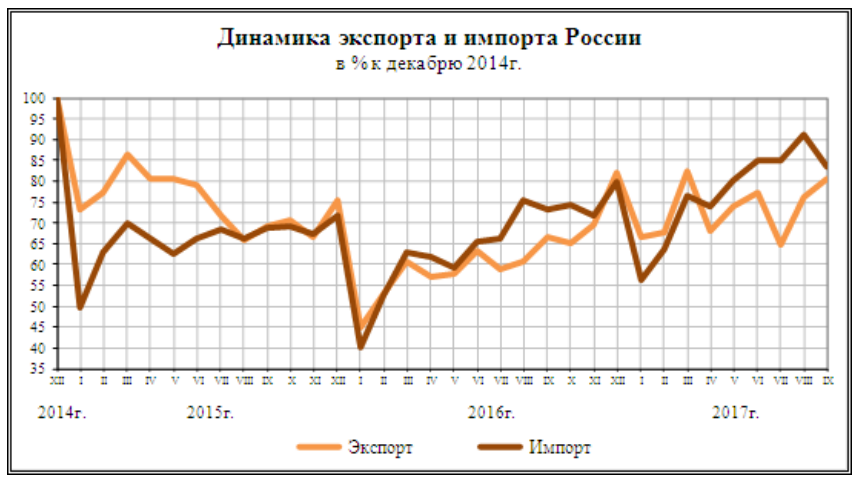

Fig. 1 Dynamics Of Export And Import From December 2014 To September 2017 Years, \%

- the complexity of the development of transport infrastructure;

- the structure of exports and imports in Russia, namely: mainly finished products applicable for container are imported into Russia, and fuel and raw materials are exported, for the transportation of which containers cannot be used;

- organizational and economic disadvantages, for example: high inflexible tariffs, downtime at customs [6].

These two years have become indicative of the development of international logistics in Russian. The state needed a search for new export-import directions. The role, significance and requirements for international logistics is increasing. Functions of international logistics are the transportation of goods between enterprises located in different countries, the storage of goods on the way, customs procedures, the organization of the coordinated work of the enterprises involved in the delivery. Every year, the requirements for quality indicators of international logistics are increasing. Only large international logistics companies have agencies in many countries. a wide network of intermediaries is provided by advanced technical and technological means. also various associations of logistics companies that are able to function effectively in contemporary conditions.

Sanctions and response activities by the Russian Government had a significant impact on Russian enterprises entering the international market. The Russian Federation stopped importing consumer goods and food. Abormal losses were suffered by carriers transporting agricultural products from Poland and other European countries.

For five years (2013 - 2018), during which Russian exports were subject to sanctions, domestic enterprises acquired new foreign partners and set a positive trend in export growth (table 1) [4].
TABLE I. CHANGES EXPORT EARNINIGS OF RUSSIAN IN 2018 COMPARED TO 2013 YEARS (BILLION RUB.)

\begin{tabular}{|l|c|}
\hline \multicolumn{1}{|c|}{ Product export } & $\begin{array}{c}\text { Export } \\
\text { earning }\end{array}$ \\
\hline Mineral products & 6260,5 \\
\hline Metals and Products & 1534,7 \\
\hline Foodstuffs & 1044,0 \\
\hline Engineering and equipment products & 894,9 \\
\hline Chemical industry products & 734,1 \\
\hline Forest products & 526,1 \\
\hline Other goods & 237,1 \\
\hline Gemstones and Metals & 178,9 \\
\hline Textiles, Textile Products & 44,0 \\
\hline Leather raw materials, furs & 3,4 \\
\hline
\end{tabular}

As a result of economic sanctions, the Russian logistics complex received an impetus for development using digital solutions. There are new movements of material flows, as well as the accompanying information, financial and energy flows both within the country - to the Crimea and beyond with the countries of Latin America, China, the Republic of Belarus and the Republic of Kazakhstan [7].

It should also be noted the main transformational factors that form certain logistics trends, especially this affects the transport industry. One of the main factors is digitalization, which has changed contractual and operational processes. The impact of this factor immediately revealed a number of problems, such as the need to finalize the legal aspect; lack or insufficient number of competent and qualified personnel who would own contemporary information technologies and, as a result of the introduction of digital technologies, consumer behavior changes. The second factor is associated with the introduction of new software, which allows you to quickly increase business efficiency, this is especially true in the field of cargo transportation. The third factor affecting the domestic and foreign markets was the changes in international trade associated with the conclusion of free trade agreements; implementation of the "One Belt and One Way" initiative; internationalization of transport services; increased trade between Europe and Asia.

The active development of trade relations and, as a result, the increase in material flows with East Asian countries and China contributed to the development and construction of the New Silk Road, part of which should pass through the territory of the Russian Federation. Participation in this project is promising for the development of international logistics in Russia. However, due to foreign policy obstacles, it is highly likely that the transport corridor will bypass the Russian Federation.

It should be noted that according to the World Trade Organization, in 2016, Russia ranks 9th among the world's largest exporters. However, an interesting fact is that in the forecasting issue of the logistics market and Russia's GDP, analysts are guided by the patterns of fluctuations in the tenyear schedule of road freight transport from the EU to the Russian Federation. According to the research, the volume of import traffic will recover to the level of 2013 by 2020. These forecasts are supported by data from the report of the International Monetary Fund, which established an increase in imported goods in Russia at $6.9 \%$ in 2017 and $3.1 \%$ in 2018, and full compensation for the volumes that the freight 
market lost in 2015, experts The IMF is expected by 2022. According to M.A. Research, the average annual growth rate of the Russian market of transport and logistics services for the period 2017-2020. can make up 7.5\%. The highest dynamics will be observed in the segment of transport services - approximately $7.7 \%$ [8]. This will be facilitated by the gradual restoration of the domestic cargo base and import freight traffic as a result of increased investment activity and increased demand from the cargo-forming industries, mainly in the sphere of industrial production and construction. Optimism regarding the growth of the Russian economy was recently supported by several international rating agencies. According to the expectations of Standard \& Poor's, Russia's real GDP increased by $1.8 \%$ in 2017 , in 2017-2020. the average growth rate will be $1.7 \%$. Fitch set the GDP growth of the Russian Federation in 2017 at 2\%, and in 2018-19. by $2.1 \%$. [9]

According to the Minister of Economy of the Republic of Turkey Nihat Zeybekchi, Turkey expects that the growth in trade with Russia will increase by $35 \%$ annually and reach \$ 100 billion by 2020 . Such a statement was made following a meeting of the intergovernmental Russian-Turkish commission on trade and economic cooperation in October. In the period 2012-2014. the annual trade turnover between Russia and Turkey was at the level of 30 billion dollars [10].

However, despite the positive dynamics of these indicators, Russia is still in the ranking of the most backward countries in the world. In 2014, the World Economic Forum published a study on the involvement of various countries in world trade. Russia ranked 112 out of 132 in the ranking, between Kyrgyzstan and Lesotho. The leaders of the ranking are Singapore, Hong Kong and Denmark. Russia received the lowest ratings for the degree of accessibility of the external and internal markets (129th place) due to high customs tariffs and non-tariff regulation measures. By the degree of simplification of customs procedures - at 127 th place. In terms of transparency of border crossing, Russia got 113th place, about $21.3 \%$ of the companies surveyed noted the presence of corruption at Russian customs [11].

Before the outbreak of the foreign policy conflict, the Netherlands was the main importer of Russian goods. However, after 2015, priority shifted towards the East. Currently, the main partner of the Russian Federation is China. The total volume of Russian exports to this country increased from \$ 35.6 billion in 2013 to \$ 56 billion in 2018 [12].

Currently, the position of the Russian Federation in the international market has improved slightly. Since 2016, there has been a positive trend in export and import indicators (results 2) [4].

However, for the further development of logistics at the international level, Russia has to solve the following problems that require a comprehensive solution from the state:

1. The presence of territorial and structural imbalances in the development of transport infrastructure;

2. Insufficient quality of transport services, poor road conditions;

3. Low level of use of transit potential;

4. Low level of technological and industrial base;
5. Inadequate level of transport security, etc

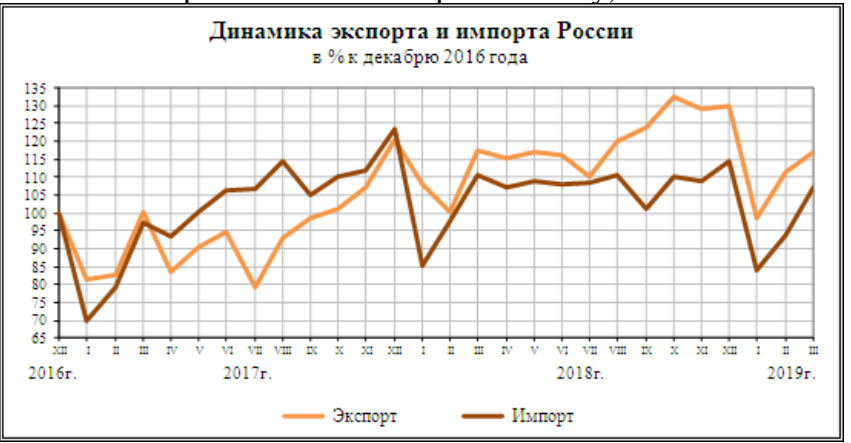

Fig. 2 Dynamics Of Export And Import From December 2016 To March $2019, \%$

Thanks to a single customs space, which was formed by the EAEU Customs Union, Russia received new trading partners in the face of the participating countries. Despite the sanctions and a decrease in the activity of foreign economic activity, the Russian market of logistics services continues to work and develop due to the reorientation of its activities to other areas of cargo transportation. The unique geographical position of Russia determines the country's main competitive advantages and sets the direction for the development of international logistics. Today, experts identify a number of international logistics trends:

- Takeover of smaller companies by large ones;

- Association of transport companies in alliances;

- Development of supply chain management;

- Growing role of logistics intermediaries.

All the above trends, their formation and further development are characterized by the use of a large amount of electronic information. Among the information concepts and technologies that have the greatest impact on logistics in international business are Electronic Document Inter Change-EDI, which replaces conventional paper documents, Electronic Funds Transfer-EFT, coding of goods and packaging of goods (bar and radio frequency), satellite tracking of vehicles (GPS / GLONASS) [13]. In international business, the introduction of electronic document management takes place at various stages of the transaction: the conclusion of a contract of sale, customs clearance, transportation, and more. The international logistics was greatly influenced by the introduction of electronic declaration of goods during customs processing of goods. In the EU, mandatory electronic declaration of goods was introduced in 2004, which significantly accelerated and facilitated the passage of customs formalities by participants of foreign economic activity [14].

Thus, it can be noted that there are a number of tools and methods for supply chain management. For example, one of the most productive logistics audit systems on the Russian market is Logistics Field Audit technology (LFA, USA). It processes a block of information that helps the company most effectively evaluate the results of its activities and eliminate shortcomings.

One of the key aspects of supply chain management is planning or logistic budgeting. With the help of planning, the company has the opportunity to predict future demand, 
delivery time, which will subsequently affect the quality of the actions in the field of logistics. There are a number of information systems that fall into two major blocks - SCP supply chain planning and SCE real-time supply chain execution. The most popular world-class information systems are:

1. Just-In-Time (JIT);

2. Efficient Consumer Response (ECR);

3. Vendor Management Inventory (VMI);

4. Collaborative Planning (CPRF).

Currently, the presence of a high level of digitalization and integration allows transport companies to adapt more quickly in the field of cargo transportation, the results are presented in table 2:

TABLE 2 INFLUENCE OF DigitALIZATION ON THE TRANSPORT AND LOGISTICS INDUSTRY AND ITS ADAPTATION TO CHANGE (\%)

\begin{tabular}{|l|c|}
\hline \multicolumn{1}{|c|}{ Indicator } & $\begin{array}{c}\text { The share of } \\
\text { companies } \\
\text { engaged in the } \\
\text { transportation of } \\
\text { goods with a high } \\
\text { level of } \\
\text { digitalization and } \\
\text { integration }\end{array}$ \\
\hline Horizontal Value Chain Integration & $44 \%$ \\
\hline $\begin{array}{l}\text { Customer access to manufacturer } \\
\text { systems, sales channels and } \\
\text { marketing }\end{array}$ & $37 \%$ \\
\hline Vertical Value Chain Integration & $36 \%$ \\
\hline General digitalization & $28 \%$ \\
\hline Design and product development & $25 \%$ \\
\hline $\begin{array}{l}\text { Digital business models, product } \\
\text { and service portfolio }\end{array}$ & $21 \%$ \\
\hline \multicolumn{2}{|c|}{ Five factors affecting the development of the transport and } \\
logistics industry. Overview of transport and logistics \\
development trends in 2019/www.pwc.ru
\end{tabular}

An integral aspect of the supply chain at the international level is the distribution channels - a partially ordered set of various intermediaries carrying out the flow of material from a particular manufacturer to its consumers. These channels differ in the number of intermediaries, in the relation between producer and consumer, by type of distribution. Distribution channels allow the company:

1. Save money on distribution;

2. Invest savings in main production;

3. Sell products in a more efficient way;

4. Reduce distribution work;

5. Provide a high degree of product availability.

As mentioned above, the development of the logistics infrastructure in Russia is hindered by a number of factors: the complexity of the development of transport infrastructure, problems of an organizational and economic nature. In general, today there are some trends in international logistics, namely:

1. Takeover of smaller companies by large;

2. Association of transport companies in alliances;

3. Development supply chain management;

4. Growing role of logistics intermediaries.
Below are the data on freight traffic published by the Federal State Statistics Service (table 3).

TABLE 3 CARgo Transportation AND CARgo TurnOvER [15]

\begin{tabular}{|c|c|c|c|c|c|}
\hline & 2005 & 2010 & 2015 & 2016 & 2017 \\
\hline \multicolumn{6}{|c|}{ Cargo transportation in Russia } \\
\hline $\begin{array}{l}\text { Cargo transported by } \\
\text { all means of transport } \\
\text { (in\% to the previous } \\
\text { year) }\end{array}$ & 102,1 & 103,8 & 98,6 & 101,7 & 101,5 \\
\hline $\begin{array}{l}\text { Cargo turnover for all } \\
\text { modes of transport } \\
\text { (in } \% \text { to the previous } \\
\text { year) }\end{array}$ & 102,6 & 106,9 & 100,6 & 101,8 & 105,5 \\
\hline $\begin{array}{l}\text { Cargo transported in } \\
\text { containers by transport } \\
\text { (million tons): } \\
\text { by rail } \\
\text { marine } \\
\text { inland water }\end{array}$ & $\begin{array}{c}17,4 \\
3,1 \\
0,3\end{array}$ & $\begin{array}{c}23,0 \\
1,4 \\
0,7\end{array}$ & $\begin{array}{c}28,6 \\
1,2 \\
0,4\end{array}$ & $\begin{array}{c}32,0 \\
1,4 \\
0,3\end{array}$ & $\begin{array}{c}37,8 \\
1,4 \\
0,3\end{array}$ \\
\hline $\begin{array}{l}\text { Transported by } \\
\text { packages (mln tons): } \\
\text { by rail } \\
\text { marine } \\
\text { inland water }\end{array}$ & $\begin{array}{c}12,2 \\
1,1 \\
0,5\end{array}$ & $\begin{array}{c}14,7 \\
0,5 \\
0,3\end{array}$ & $\begin{array}{c}25,7 \\
0,4 \\
0,5 \\
\end{array}$ & $\begin{array}{c}31,0 \\
0,3 \\
0,2 \\
\end{array}$ & $\begin{array}{c}27,8 \\
0,4 \\
0,2 \\
\end{array}$ \\
\hline \multicolumn{6}{|c|}{ Transportation of goods in international traffic } \\
\hline $\begin{array}{l}\text { Freight transported by } \\
\text { mode of transport } \\
\text { (mln tons): } \\
\text { marine } \\
\text { inland water } \\
\text { by air }\end{array}$ & $\begin{array}{c}12,4 \\
29,3 \\
0,4\end{array}$ & $\begin{array}{c}27,8 \\
17,0 \\
0,7\end{array}$ & $\begin{array}{c}8,0 \\
27,1 \\
0,6\end{array}$ & $\begin{array}{c}8,1 \\
30,5 \\
0,7\end{array}$ & $\begin{array}{c}7,9 \\
29,7 \\
0,9\end{array}$ \\
\hline $\begin{array}{l}\text { Cargo turnover } \\
\text { (billion tons } * \mathrm{~km} \text { ): } \\
\text { marine } \\
\text { inland water } \\
\text { by air }\end{array}$ & $\begin{array}{c}41,7 \\
43,8 \\
2,0\end{array}$ & $\begin{array}{c}87,7 \\
22,3 \\
3,8 \\
\end{array}$ & $\begin{array}{c}26,7 \\
34,3 \\
4,8\end{array}$ & $\begin{array}{c}30,2 \\
38,2 \\
5,8\end{array}$ & $\begin{array}{c}33,5 \\
35,9 \\
7,0\end{array}$ \\
\hline
\end{tabular}

The analysis of table 3, reflecting the dynamics of cargo transportation showed that, despite a slight drop in the results at the levels of 2010 and 2015 (this decrease was due to the financial economic crisis of 2008-2010 and the sanctions introduced in 2014), for all types of transportation of goods and cargo turnover, both in the domestic market and in the international communications market, there is a small but stable increase in indicators. On this basis, experts make positive forecasts regarding the Russian situation, which is confirmed by the country's gross domestic product growth and the gradual restoration of import traffic.

\section{RESULTS}

A study of the prospects for the development of international loyalty and its inherent foreign economic activity in the context of digitalization showed the positive dynamics of export-import operations in the Russian Federation, a decrease in logistics flows in the western direction and their reorientation to the east. The current situation on the international market requires streamlining a large number of intermediaries involved in foreign economic activity, the efficiency of this process is increased due to the introduction of new software. 


\section{DISCUSSION}

There is a need to develop transport infrastructure in Russia, which should be included in international transport corridors. Such an approach using digital solutions will increase revenue from export-import operations in the country's foreign economic activity and will form new information and communication business models in international logistics.

\section{CONCLUSIONS}

Thus, the state and prospects of the development of international logistics of the countries of Europe and Russia in the post-sanction period in the context of the development of digitalization were examined. It is worth noting that the logistics of the European countries went far ahead compared to the logistics of Russia, first of all, this is due to the growth of cargo turnover in Europe, with a more updated transport infrastructure, and the widespread use of container transportation. Nevertheless, the introduction of digitalization in the transport industry of Russia forms new trends in international logistics.

\section{REFERENCES}

[1] Bataev, A.V., Bataeva, K.I. Analysis of Performance Indicators of Russian Universities in the International Arena (2019) 8604203, pp. 11-14.

[2] Evseeva, S., Kalchenko, O., Evseeva, O. Innovative projects for sustainable development of cities (case of Saint-Petersburg) (2018) $170,02007$.

[3] Zaychenko, I., Borremans, A., Gutman, S. Analysis of administrative barriers in the industry of the high-rise construction in Russian Federation (2018) 33, 03010.
[4] Federal office of State Statistics

URL: http://www.gks.ru/free_doc/2019/b19_01/vn-t.htm

[5] Maydanova, S., Ilin, I. Problems of the preliminary customs informing system and the introduction of the Single Window at the sea check points of the Russian Federation (2018) MATEC Web of Conferences, 239, статья № 04004

[6] Mirotin L.B. Logistics: Management in Transport Systems. Study Guide (in Russian) - M.: YUrist", 2002. - 414 s. ISBN 5-79750523-1.

[7] Dubgorn, A., Zaychenko, I., Grashhenko, N. A rationale for choosing the mechanism of public-private partnership for the sustainable development of social infrastructure facilities. MATEC Web of Conferences. Volume 170, 13 June 2018, Number 010562017.

[8] Economics and logistic market in Russia in 2017-2018. URL: https://logistics.ru/.

[9] Current tendencies in Russian economy. Dynamics and the structure of the GDP (2019) URL: http://ac.gov.ru/files/publication/a/21979.pdf

[10] Muryseva YU. Logistics development. URL: https://pandia.ru/text/80/394/732.php

[11] Khalipova N.V. International logistics systems design and effectiveness evaluation, 2017. -5 .

[12] Logirus. Logistics in Russia. URL: http://logirus.ru/.

[13] Alesinskaya, T.V., Arutyunova, D.V., Orlova, V.G., Ilin, I.V., Shirokova, S.V. Conception BSC for investment support of port and industrial complexes (2017) Academy of Strategic Management Journal, 16 (Specialissue1), pp. 10-20.

[14] Orlova, V., Ilin, I., Shirokova, S. Management of port industrial complex development: Environmental and project dimensions (2018) MATEC Web of Conferences, 193, 05055.

[15] I.A. Krasyuk, S.M. Krymov, Y.Y. Medvedeva, A.M. Chernisheva, S.I. Lashko, "Marketing management in retail chains," International Journal of Applied Business and Economic Research, 2017, vol. 15(12), pp. 83-91.

[16] Donald F. Wood, Anthony P. Barone, Paul R. Jr. Murphy, Daniel L. Wardlow International Logistics // Monography, 2013. - 43-45.

[17] Joshi D. International logistics: The essence of success in IMPEX, 2015. $-101-102$. 